\title{
Correction: An unusual presentation of pulmonary embolism leading to infarction, cavitation, abscess formation and bronchopleural fistulation
}

Teng E, Bennett L, Morelli T, et al. An unusual presentation of pulmonary embolism leading to infarction, cavitation, abscess formation and bronchopleural fistulation. BMJ Case Rep 2018. doi: 10.1136/bcr-2017-222859.

In this case report, figures 4 and 5 are incorrectly the same. While figure 4 is correct, please see below the correct figure 5. The red arrow indicates a leftsided pulmonary filling defect consistent with acute pulmonary embolism.

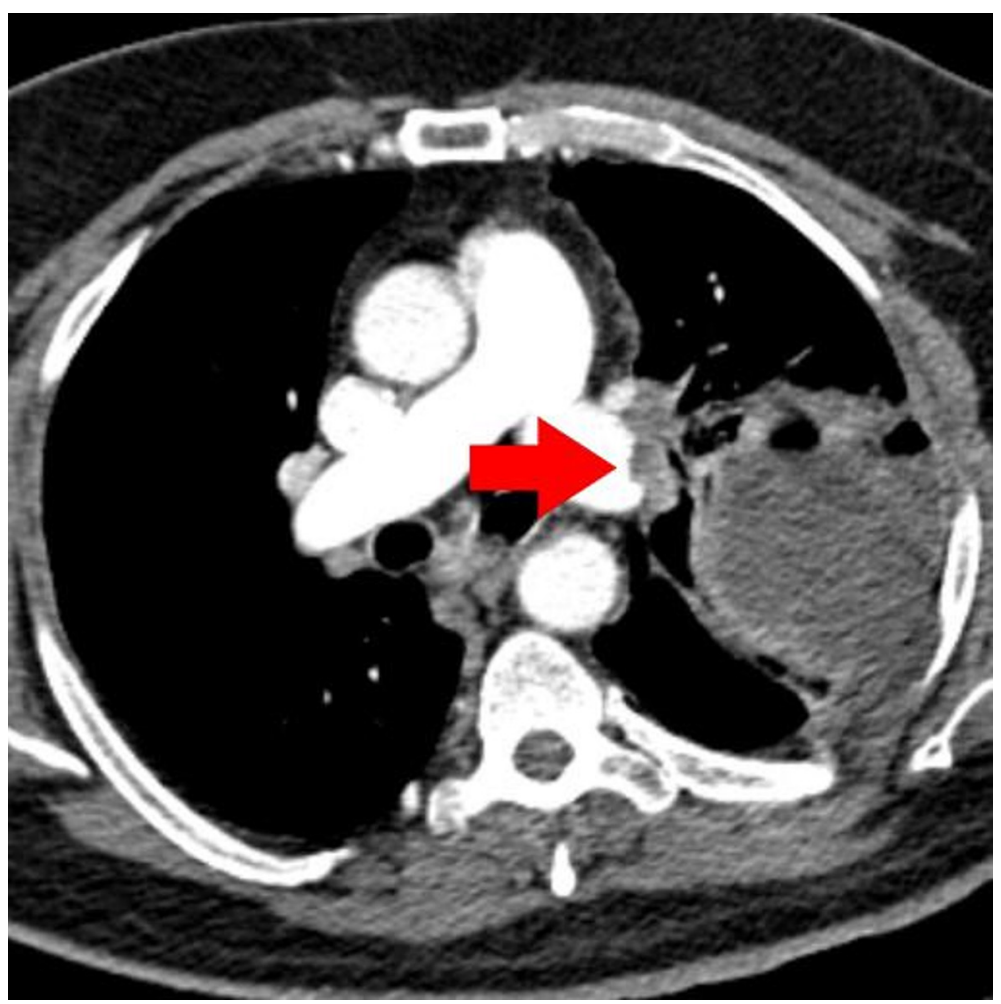

(C) BMJ Publishing Group Ltd (unless otherwise stated in the text of the article) 2018. All rights reserved. No commercial use is permitted unless otherwise expressly granted.

BMJ Case Rep 2018. doi:10.1136/bcr-2017-222859corr1

(A) Check for updates

Copyright 2018 BMJ Publishing Group. All rights reserved. For permission to reuse any of this content visit http://group.bmj.com/group/rights-licensing/permissions.

BMJ Case Report Fellows may re-use this article for personal use and teaching without any further permission.

Become a Fellow of BMJ Case Reports today and you can:

- Submit as many cases as you like

- Enjoy fast sympathetic peer review and rapid publication of accepted articles

- Access all the published articles

- Re-use any of the published material for personal use and teaching without further permission

For information on Institutional Fellowships contact consortiasales@bmjgroup.com

Visit casereports.bmj.com for more articles like this and to become a Fellow 